\title{
Physico-Chemical and Microbiological Study for the Stability of Phenytoin Sodium Extemporaneously Compounded Suspension in Saudi Arabia Hospitals
}

\author{
Syed Ata ur Rahman 1,2, Abdullah Alsaedi', Abdulelah Alhusayni', Abdulmalik Alqurshi', \\ Sameh Ahmed ${ }^{3}$, Yaser M. Alahmadi ${ }^{4}$, Alaa Omer M. Abdullaal5, Badr Ahmed A. Taher5, \\ El-Sayed E. Habib1,6
}

\author{
${ }^{1}$ Department of Pharmaceutics and Pharmaceutical Technology, College of Pharmacy, Taibah University, \\ Madinah Munawwarah, Kingdom of Saudi Arabia \\ ${ }^{2}$ Department of Pharmacy, College of Health Sciences and Nursing, AlRayan College, Madinah Munawwarah, \\ Kingdom of Saudi Arabia \\ ${ }^{3}$ Department of Pharmacognosy and Pharmaceutical Chemistry, College of Pharmacy, Taibah University, \\ Madinah Munawwarah, Kingdom of Saudi Arabia \\ ${ }^{4}$ Department of Clinical and Hospital Pharmacy, College of Pharmacy, Taibah University, Madinah Munawwarah, \\ Kingdom of Saudi Arabia \\ ${ }^{5}$ Pharmacy Department, Madinah Maternity and Children Hospital, Madinah Munawwarah, Kingdom of Saudi Arabia \\ ${ }^{6}$ Department of Microbiology and Immunology, Faculty of Pharmacy, Mansoura University, Mansoura, Egypt \\ Email: saur9186@gmail.com, sa.urrahman@amc.edu.sa
}

How to cite this paper: ur Rahman, S.A., Alsaedi, A., Alhusayni, A., Alqurshi, A., Ahmed, S., Alahmadi, Y.M., Abdullaal, A.O.M., Taher, B.A.A. and Habib, E.-S.E. (2021) Physico-Chemical and Microbiological Study for the Stability of Phenytoin Sodium Extemporaneously Compounded Suspension in Saudi Arabia Hospitals. Pharmacology \& Pharmacy, 12, 1-9. https://doi.org/10.4236/pp.2021.121001

Received: November 30, 2020

Accepted: January 16, 2021

Published: January 19, 2021

\begin{abstract}
Epilepsy is a chronic and the fourth most common neurological disorder which affects people of all age groups. Recently research and awareness on epilepsy-related deaths have rapidly grown over the past two decades. Many previous studies are attributed to the guidelines that apprise health care professionals in handling these deaths, but there is a relative scarcity of information accessible for clinicians and pharmacists who are responsible for manufacturing or preparing the extemporaneous anti-epileptic suspensions in the hospitals. Mostly in partial seizures, phenytoin is one of the first-choice drugs. In Saudi Arabian hospitals, the extemporaneous preparation of phenytoin suspension is common, but the hot climatic weather in Saudi Arabia possesses stability problems that should be tackled as the prepared suspension should pass all the stability tests to ensure uniform dosage of the extemporaneous formulation. In the current study, the commercial capsules were used to prepare the oral phenytoin sodium extemporaneous suspension. The physical, chemical and microbiological stability of phenytoin sodium suspen-
\end{abstract}


Copyright (c) 2021 by author(s) and Scientific Research Publishing Inc. This work is licensed under the Creative Commons Attribution International License (CC BY 4.0).

http://creativecommons.org/licenses/by/4.0/ sion is analyzed at various temperatures.

\section{Keywords}

Physical Stability, Phenytoin, Extemporaneous Preparation, Chemical Stability, Epilepsy

\section{Introduction}

Epilepsy is a chronic, non-contagious disease of the brain which affects people of all ages. As stated by a World health organization (WHO) analysis, worldwide 50 million people suffer from epilepsy, thus making it one of the most common neurological disorders [1]. It is a noncommunicable chronic disease of the brain where electrical imbalances occur. If properly diagnosed and treated, almost $70 \%$ of patients affected by epilepsy could survive a convulsion-free life [1]. Due to epilepsy the mortality rate is impetuously increasing and is three times greater than the death rate of the general population [1].

Phenytoin is an efficacious anti-epileptic drug that is used to prevent focal and tonic-clonic seizures (grand mal seizure) [2]. It is commercially sold in both solid and liquid dosage form as a chewable tablet, extended-release capsule and oral suspension as well. Phenytoin is used in neonates, infants and children as an oral suspension form which is not readily available most of the time [3]. Thus, to overcome the non-availability most hospitals in Saudi Arabia prepare the extemporaneous oral suspensions from capsules by dissolving them in an alternative vehicle in the absence of suitable suspending vehicles. The suspension form allows the patient to intake when swallowing difficulties are observed. Thus, the stability of such formulations is crucial [4].

A pharmaceutical formulation needs vigilant determination to ensure a uniform drug distribution while administration as sedimentation may occur which will result in inhomogeneous dosage [5]. A standard formulation will maintain its stability under all relevant conditions. In many previous studies, the stability of such extemporaneous formulations has been conducted, but in the cold to moderate climates i.e., temperature range from $4^{\circ} \mathrm{C}-25^{\circ} \mathrm{C}$ only.

In the current research, various temperature ranges have been covered i.e. temperature range from $4^{\circ} \mathrm{C}, 25^{\circ} \mathrm{C}, 40^{\circ} \mathrm{C}$ and $54^{\circ} \mathrm{C}$, so that, in some middle east countries where the temperature rises up to $54^{\circ} \mathrm{C}$ during summer can also be observed [6]. These countries encounter issues in maintaining the stability of such pharmaceutical formulations during transportation and other various conditions [7]. Moreover, it will be unfavorable for middle wage earners to find a suitable storage condition i.e., below $25^{\circ} \mathrm{C}$ to store these formulations.

This study aims to analyze the physicochemical and microbiological stability of extemporaneous suspension of an anti-convulsant drug i.e., Phenytoin Sodium in various temperature range i.e., temperature range from $4^{\circ} \mathrm{C}$ to $54^{\circ} \mathrm{C}$, thus observing the stability in high climatic conditions. 


\section{Materials and Methods}

This study was conducted at Taibah university research laboratory, Madinah Munawara, Saudi Arabia, between April 2019 to May 2020.

\subsection{Chemicals and Reagents}

Capsules containing $100 \mathrm{mg}$ of phenytoin sodium (commercially available in Saudi Arabia) were used. Fluka analytical, US A supplied dextrose. Acetonitrile was of HPLC gradient grade obtained from Honeywell, CHROMASOLV ${ }^{\circledR} \geq$ 99.9\%, Germany. The standard $\mathrm{pH}$ calibration solutions (4.0 and 7.0) were purchased from Fisher Scientific, UK. All the other reagents and chemicals used were of analytical grade and purchased from Fluka analytical, USA and purified water was provided using a (Direct 8) Milli- ${ }^{\circledR}$ system of water purification, France.

\subsection{Extemporaneous Preparation}

The oral Phenytoin sodium extemporaneous suspension $(20 \mathrm{mg} / \mathrm{mL})$ was prepared by suspending capsules. According to the USP 39/NF 34, the structured suspension vehicle was prepared which consist of dextrose $(50 \% \mathrm{w} / \mathrm{v})$ and purified water (1:3) [8]. The suspensions were filled in polyethylene plastic bottles and stored at $4^{\circ} \mathrm{C}, 25^{\circ} \mathrm{C}, 40^{\circ} \mathrm{C}$ and $54^{\circ} \mathrm{C}$ for up to 28 days. All samples were preserved from light.

\subsubsection{Physicochemical Stability Test}

Physical characteristics, including color, odor, $\mathrm{pH}$, viscosity and sedimentation volume were tested every week. Chemical stability was tested by a validated reverse phase HPLC assay (Shimadzu SIL-10AP), using a mixture of acetonitrile and $10 \mathrm{mM}$ phosphate buffer $(\mathrm{pH}=3.5)(40: 60)$ as a mobile phase, while monitoring effluent at $220 \mathrm{~nm}$.

\subsection{2. pH Measurement}

The $\mathrm{pH}$ of phenytoin sodium suspension extemporaneous preparation was measured by $\mathrm{pH}$ meter (Hanna-pH 211, USA) on days 0 and 28. The $\mathrm{pH}$ meter was calibrated using a Fisher Scientific, UK standard buffer solutions $(\mathrm{pH} 4.0$ and $\mathrm{pH} 7.0)$.

\subsubsection{Sedimentation}

The phenytoin sodium extemporaneous suspension was stored in a $100 \mathrm{~mL}$ measuring cylinder at $4^{\circ} \mathrm{C}, 25^{\circ} \mathrm{C}, 40^{\circ} \mathrm{C}$ and $54^{\circ} \mathrm{C}$ after preparation. The sediment of suspensions was recorded on days 0 and 28. The volume of sedimentation was determined by $F=V u / V o$; where $F=$ volume of sedimentation, $V u=$ sediment volume $(\mathrm{mL})$ and $V o=$ suspension volume $(\mathrm{mL})$, respectively.

\subsubsection{Viscosity}

The phenytoin sodium extemporaneous suspension was kept at $4^{\circ} \mathrm{C}, 25^{\circ} \mathrm{C}, 40^{\circ} \mathrm{C}$ and $54^{\circ} \mathrm{C}$ and the viscosity were determined on days 0 and 28 . The viscosity was 
recorded using Rotational Viscometer (Cannon-Model 2020) using spindle LV1 at various speeds of 20,50 , and $100 \mathrm{rpm}$, respectively.

\subsection{Microbial Stability Test}

A microbiological test of the Phenytoin suspension was performed according to the United States Pharmacopeia monograph, Microbiological examination of non-sterile product [9]. Microbiological stability was performed on Phenytoin suspension stored for 4 weeks at $4^{\circ} \mathrm{C}, 25^{\circ} \mathrm{C}, 40^{\circ} \mathrm{C}$ and $54^{\circ} \mathrm{C}$. Total aerobic microbial count (TAMC), total combined yeast and moulds (TYMC) and E. coli were examined. The suspension was diluted with Müller-Hinton Broth in a dilution of 1:10. A portion of diluted suspension was then streaked on Tryptic Soy Agar (TSA) plate for bacteria determination. The plates were incubated at $37^{\circ} \mathrm{C}$ for 24 - 48 hours to check the presence of bacteria. While, to detect the presence of yeast and mould, the diluted suspension was streaked on the Sabouraud-Dextrose Agar (SDA) plate. The plates were incubated at $25^{\circ} \mathrm{C}$ for $120-144$ hours. For examination, the presence of E. coli, the diluted suspension was used to inoculate in $100 \mathrm{ml}$ Tryptic Soy Broth (TSB) and incubated at $37^{\circ} \mathrm{C}$ for 24 hours, this broth sample was sub cultured on a MacConkey agar plate and incubated at $37^{\circ} \mathrm{C}$ for $24-48$ hours, E. coli can be detected as the growing of brick-red colonies.

The Microbial count was considered to be the average number of colony-forming unit (cfu) growing on agar. The experiment was performed in a triplicate.

After stability storage, all samples were transferred to a validated $4^{\circ} \mathrm{C}$ storage unit scheduled for testing. On the testing day, samples were moved into a $25^{\circ} \mathrm{C}$ water bath allowing them to reach room temperature, following so samples were shaken well and tested for appearance and smell, $\mathrm{pH}$ level and sedimentation volume.

\subsection{Ethical Consideration}

The ethical acceptance was sought and successfully obtained from the Taibah University ethics committee to carry out the research.

\section{Results and Discussion}

\subsection{Physico-Chemical Stability}

\subsubsection{Drug Analysis}

The HPLC technique was adopted to determine Phenytoin sodium. The retention duration of phenytoin sodium was $4.2-4.6$ mins respectively (Figure 1). The results displayed that the percent concentration of phenytoin sodium constantly remained above $90 \%$ of the initial concentration after storage for 28 days at $4^{\circ} \mathrm{C}, 25^{\circ} \mathrm{C}, 40^{\circ} \mathrm{C}$ and $54^{\circ} \mathrm{C}$ in polyethylene plastic containers. The initial concentration percentage was in a range of $72.64 \%-99.78 \%$ as illustrated in Figure 2 . 

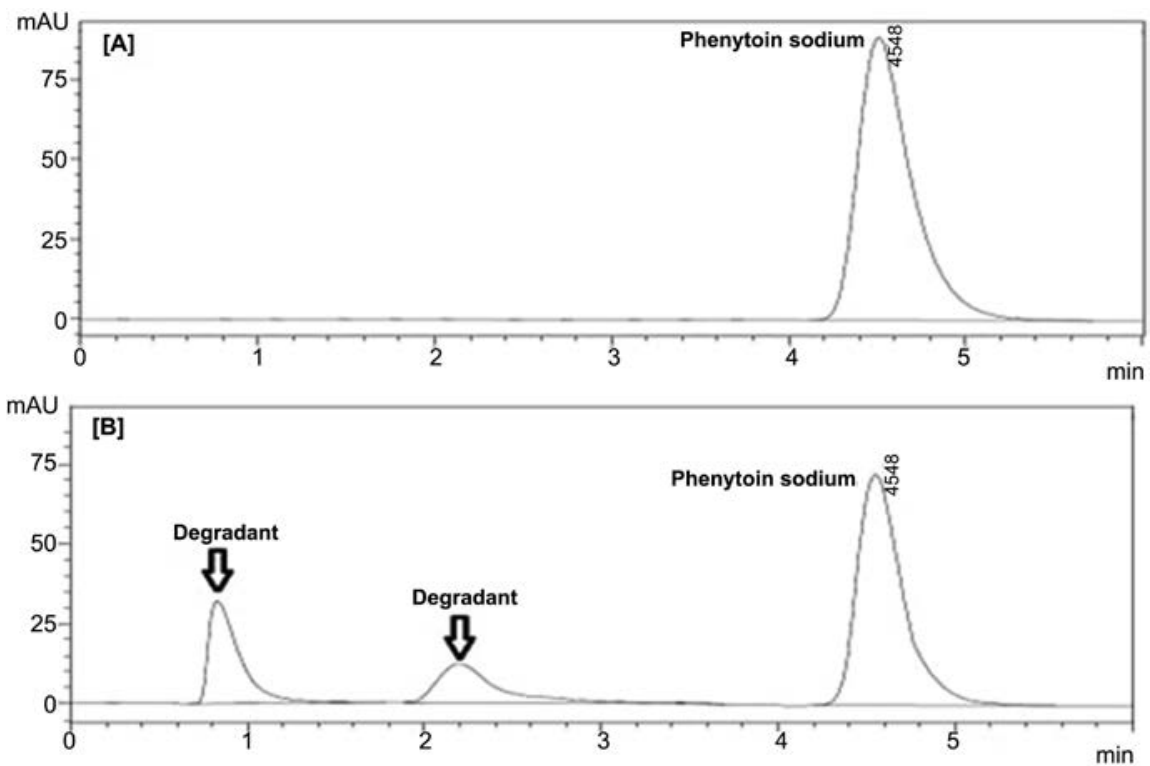

Figure 1. HPLC Chromatograms of phenytoin sodium extemporaneous suspension. [A] QC sample. [B] After storage at $54^{\circ} \mathrm{C}$ for 28 days.

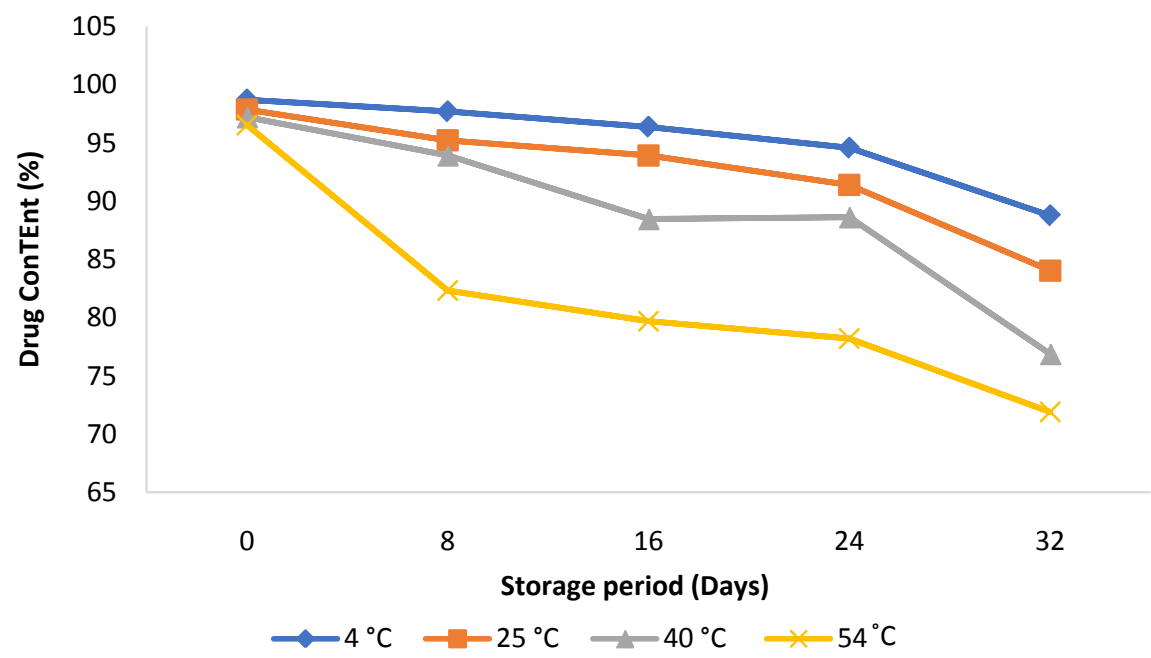

Figure 2. Monitoring of drug content for 32 days.

Drug content percentage of $20 \mathrm{mg} / \mathrm{ml}$ phenytoin sodium extemporaneous preparation after storage in polyethylene plastic container at $4^{\circ} \mathrm{C}, 25^{\circ} \mathrm{C}, 40^{\circ} \mathrm{C}$ and $54^{\circ} \mathrm{C}$ on days $0,8,16,24$ and 32 .

\subsection{2. $\mathrm{pH}$ Measurement}

The results concluded that the $\mathrm{pH}$ of phenytoin sodium suspension structured vehicle was about $4.2-4.3$. The $20 \mathrm{mg} / \mathrm{mL}$ oral phenytoin sodium extemporaneous suspension was observed white foamy and readily re-dispersible suspension. After freshly prepared, the $\mathrm{pH}$ of phenytoin sodium extemporaneous suspension increased to 10.57 , this elevation of $\mathrm{pH}$ was caused due to the sodium salt of the drug. The $\mathrm{pH}$ values were rather constant in a range of $4.56-10.57$ after storage for 28 days (Table 1 ). 
Table 1. Appearance, smell and $\mathrm{pH}$ of phenytoin sodium after storage at $4^{\circ} \mathrm{C}, 25^{\circ} \mathrm{C}, 40^{\circ} \mathrm{C}$ and $54^{\circ} \mathrm{C}$ for 28 days.

\begin{tabular}{|c|c|c|c|c|c|c|}
\hline $\begin{array}{l}\text { Storage period } \\
\text { (days) }\end{array}$ & Sample & Appearance \& smell & Storage Temp. & pH Reading & Avg. pH & STD \\
\hline 0 & - & White foamy & $4^{\circ} \mathrm{C}$ & 10.73 & - & - \\
\hline \multirow{3}{*}{28} & A & \multirow{3}{*}{$\begin{array}{l}\text { No change in color or } \\
\text { odor }\end{array}$} & \multirow{3}{*}{$4^{\circ} \mathrm{C}$} & 10.56 & \multirow{3}{*}{10.57} & \multirow{3}{*}{0.01} \\
\hline & B & & & 10.56 & & \\
\hline & $\mathrm{C}$ & & & 10.59 & & \\
\hline \multirow{3}{*}{28} & A & \multirow{3}{*}{$\begin{array}{l}\text { Color changed to light } \\
\text { Caramel-Sweet smell }\end{array}$} & \multirow{3}{*}{$25^{\circ} \mathrm{C}$} & 8.47 & \multirow{3}{*}{8.69} & \multirow{3}{*}{0.16} \\
\hline & B & & & 8.83 & & \\
\hline & $\mathrm{C}$ & & & 8.76 & & \\
\hline \multirow{3}{*}{28} & A & \multirow{3}{*}{$\begin{array}{l}\text { Color changed to } \\
\text { Caramel-Sweet smell }\end{array}$} & \multirow{3}{*}{$40^{\circ} \mathrm{C}$} & 5.58 & \multirow{3}{*}{5.59} & \multirow{3}{*}{0.03} \\
\hline & B & & & 5.56 & & \\
\hline & $\mathrm{C}$ & & & 5.63 & & \\
\hline \multirow{3}{*}{28} & A & \multirow{3}{*}{$\begin{array}{c}\text { Color changed to dark } \\
\text { Caramel_-Post sweet } \\
\text { smell }\end{array}$} & \multirow{3}{*}{$54^{\circ} \mathrm{C}$} & 4.72 & \multirow{3}{*}{4.56} & \multirow{3}{*}{0.14} \\
\hline & B & & & 4.37 & & \\
\hline & C & & & 4.58 & & \\
\hline
\end{tabular}

\subsubsection{Sedimentation Volume}

The sedimentation volumes (F) were between 0.16 and 0.72 (Table 2). However, prominent caking and clumping of suspended particles was observed at $40^{\circ} \mathrm{C}$ and $54^{\circ} \mathrm{C}$. This result attributes that the structured vehicle of this suspension was a desirable vehicle for excellent physical stability.

\subsubsection{Viscosity}

After storing for 28 days at $4^{\circ} \mathrm{C}, 25^{\circ} \mathrm{C}, 40^{\circ} \mathrm{C}$ and $54^{\circ} \mathrm{C}$, the viscosities were significantly constant from the freshly prepared suspensions at the same speed of needle (Figure 3).

\subsection{Microbial Stability}

In nonsterile liquid formulations, the microbial contamination may generate turbidity, bad odor, and also affect appearance and palatability. Specifically, in immunocompromised patients, the elevated level of microorganisms may be hazardous to health. By-product of microorganism metabolism may induce a change in the $\mathrm{pH}$ of the preparation and reduce the chemical stability. To use extemporaneous preparation after its beyond-use date, a preservative is required. In this current study, potassium sorbate was used as a preservative in the structured suspension vehicle.

The microbial stability study indicated that the total aerobic microbial count (TAMC) was less than $8 \mathrm{cfu} / \mathrm{ml}$, while the total yeast and mold count (TYMC) was less than $3 \mathrm{cfu} / \mathrm{ml}$ in the storage conditions at $40^{\circ} \mathrm{C}$ and $54^{\circ} \mathrm{C}$ in the 4 th week. Furthermore, there was no $E$. coli or bacterial contamination detected in the MacConkey media plates of any samples. This result attributes that phenytoin 
Table 2. Sedimentation volume of phenytoin sodium extemporaneous suspensions after 28 days at $4^{\circ} \mathrm{C}, 25^{\circ} \mathrm{C}, 40^{\circ} \mathrm{C}$ and $54^{\circ} \mathrm{C}$.

\begin{tabular}{cccc}
\hline \multicolumn{4}{c}{ Sedimentation (F) } \\
\hline Storage period (days) & Storage Temp. & Avg. F. & STD \\
\hline 0 & $4^{\circ} \mathrm{C}$ & 0.28 & - \\
28 & $4^{\circ} \mathrm{C}$ & 0.33 & 0.02 \\
28 & $25^{\circ} \mathrm{C}$ & 0.72 & 0.44 \\
28 & $40^{\circ} \mathrm{C}$ & 0.19 & 0.05 \\
28 & $54^{\circ} \mathrm{C}$ & 0.16 & 0.01 \\
\hline
\end{tabular}

10.0

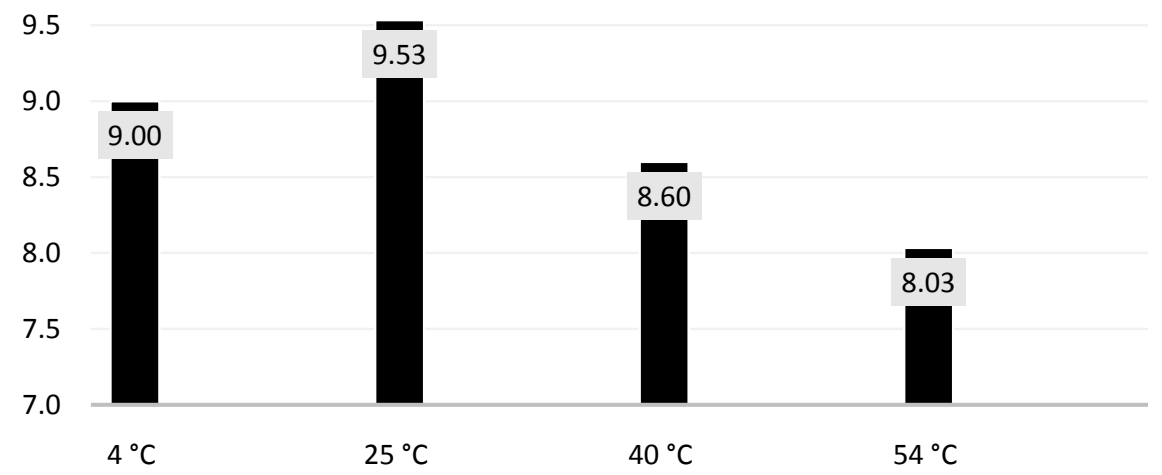

Figure 3. Viscosity of phenytoin sodium extemporaneous suspension after 28 days at $4^{\circ} \mathrm{C}, 25^{\circ} \mathrm{C}, 40^{\circ} \mathrm{C}$ and $54^{\circ} \mathrm{C}$.

sodium extemporaneous suspension met the USP specifications in the microbial examination of nonsterile product throughout 28 days [9].

The stability of a pharmaceutical formulation is defined as the ability of a product in a particular storage condition to maintain and retain within its physicochemical, toxicological, therapeutically and microbiological specifications [10]. The storage condition which is based on the climatic conditions is the most crucial aspect in the analysis of a stability study. Stability testing of pharmaceutical formulations consists of complex procedures that involve time consumption, considerable cost, and scientific expertise to build in efficacy, quality, and safety in a drug product [7].

The stability testing evaluates the effect of environmental factors on the quality of a drug substance or a formulated product that is utilized for prognosis of its shelf life and it will also determine the adequate storage conditions and moreover it will suggest labeling specifications [11]. The data produced during the stability study is a essential to get regulatory approval for any formulation or drug [12].

The phenytoin sodium extemporaneous suspension showed no remarkable changes in $\mathrm{pH}$, color, odor or sedimentation volumes after 16 days of storage at $4^{\circ} \mathrm{C}-25^{\circ} \mathrm{C}$. However, storage at $40^{\circ} \mathrm{C}-54^{\circ} \mathrm{C}$ caused a prominent caramelization 
in color and odor, as well as observable caking and clumping of suspended particles. Phenytoin sodium was in the list of top 200 drugs of 2015 with more than 1.6 million prescriptions written in 2015 in the United States alone [13].

\section{Conclusion}

Phenytoin sodium $(20 \mathrm{mg} / \mathrm{ml})$ suspension was stable for a period of up to 16 days when stored in polyethylene plastic containers between $4^{\circ} \mathrm{C}$ and $25^{\circ} \mathrm{C}$. Avoiding exposure to temperatures $>25^{\circ} \mathrm{C}$ is strongly recommended to ensure physical and chemical properties intact. The appearance and $\mathrm{pH}$ observations were intact throughout the study. The microbial stability of Phenytoin suspension showed that the TAMC was less than $8 \mathrm{cfu} / \mathrm{ml}$, while the TYMC was less than $3 \mathrm{cfu} / \mathrm{ml}$ in the storage conditions at $40^{\circ} \mathrm{C}$ and $54^{\circ} \mathrm{C}$ on the 28 th day. Moreover, there was no $E$. coli contamination detected in the MacConkey media plates of any samples. Furthermore, in the microbial examination of nonsterile products, USP specifications were met by phenytoin sodium extemporaneous suspension, but it was advised to use a buffer system for controlling the final $\mathrm{pH}$ of the prepared suspension to reduce the bitter taste of drug and ensure good microbial stability.

\section{Conflicts of Interest}

The authors declare that they have no conflict of interests and no financial support that might affect the study.

\section{References}

[1] Organization WH. (2019) Epilepsy 2019. https://www.who.int/news-room/fact-sheets/detail/epilepsy

[2] Goldenberg, M.M. (2010) Overview of Drugs Used for Epilepsy and Seizures: Etiology, Diagnosis, and Treatment. Pharmacy and Therapeutics, 35, 392-415.

[3] Slaughter, L.A., Patel, A.D. and Slaughter, J.L. (2013) Pharmacological Treatment of Neonatal Seizures: A Systematic Review. Journal of Child Neurology, 28, 351-364. https://doi.org/10.1177/0883073812470734

[4] Viriyaroj, A., Klapachan, S., Phanpleewan, C., Viriyaroj, V., Sornchaithawatwong, C. and Wiranidchapong, C. (2009) Physicochemical and Microbiological Stability of Phenytoin Sodium Extemporaneous Suspension. Thai Pharmaceutical and Health Science Journal, 4, 8.

[5] Newey-Keane, L. and Carrington, S. (2016) Controlling the Stability of Medicinal Suspensions.

https://www.americanpharmaceuticalreview.com/Featured-Articles/331619-Control ling-the-Stability-of-Medicinal-Suspensions/

[6] Almazroui, M., Islam, M.N., Jones, P.D., Athar, H. and Rahman, M.A. (2012) Recent Climate Change in the Arabian Peninsula: Seasonal Rainfall and Temperature Climatology of Saudi Arabia for 1979-2009. Atmospheric Research, 111, 29-45. https://doi.org/10.1016/j.atmosres.2012.02.013

[7] Bajaj, S., Singla, D. and Sakhuja, N. (2012) Stability Testing of Pharmaceutical Products. Journal of Applied Pharmaceutical Science, 2, 129-138. 
[8] Gong, T., Wei, Q.-W., Mao, D.-G., Nagaoka, K., Watanabe, G., Taya, K., et al. (2016) Effects of Daily Exposure to Saccharin and Sucrose on Testicular Biologic Functions in Mice. Biology of Reproduction, 95, 1-13.

https://doi.org/10.1095/biolreprod.116.140889

[9] USP 31/NF 26. (2008) Asian Edition. United States Pharmacopeial Convention Inc., 76-85, 579-581.

[10] Pharmaceutical Guidance, Drug Stability in Pharmaceutical Products 2018. https://www.pharmaguidances.com/drug-stability/

[11] Bhagyashree, P., Karishma, G., Sampada, A., Ankita, P., Chandankar, P., et al. (2015) Recent Trends in Stability Testing of Pharmaceutical Products: A Review. Research Journal of Pharmaceutical, Biological and Chemical Sciences, 6, 1557-1563.

[12] Mani, S. (2013) Stability Studies: A Review. Asian Journal of Pharmaceutical Analysis and Medicinal Chemistry, 1, 184.

[13] Phenytoin: Drug Usage Statistics. United States 2008-2018.

https://clincalc.com/DrugStats/Drugs/Phenytoin 